\title{
Investigations on arc brazing for galvanized heavy steel plates in steel and shipbuilding
}

\author{
Philipp Andreazza ${ }^{1,2}$ (D) Andreas Gericke $^{1} \cdot$ Knuth-Michael Henkel $^{1,2}$
}

Received: 3 August 2020 / Accepted: 29 January 2021 / Published online: 26 February 2021

(C) The Author(s) 2021

\begin{abstract}
Arc brazing with low-melting copper-based filler materials, which has long been established and standardized in the thin sheet sector, offers numerous advantages in the processing of predominantly electrolytically galvanized steel structures. In steel and shipbuilding, on the other hand, equipment parts made of thick steel sheets are hot-dip galvanized at low cost and with good corrosion-inhibiting properties. Quality welding of such constructions is not possible without special precautions such as removing the zinc layer and subsequent recoating. With regard to greater plate thicknesses, arc brazing was analyzed in these investigations as an alternative joining method with regard to its suitability for practical use. Within the scope of the investigations, $\mathrm{CuSi} 3 \mathrm{Mn}, \mathrm{CuMn} 12 \mathrm{Ni}$, and four different aluminum bronzes were examined on different sheet surface conditions with regard to the geometrical and production parameters. This was carried out by build-up and connection brazing, executed as butt and cross joints. Quasi-static tensile tests and fatigue tests were used to assess the strength behavior. In addition, metallographic analyses are carried out as well as hardness tests. The suitability for multi-layer brazing and the tendency to distortion were also investigated, as well as the behavior of arc brazed joints under corrosive conditions.
\end{abstract}

Keywords Arc brazing $\cdot$ Galvanized heavy steel plates $\cdot$ Steel construction $\cdot$ Copper-based alloy

\section{Introduction}

The high productivity and good handling make gas metal arc welding (GMAW) the preferred welding process for processing general construction steels in steel and shipbuilding. However, it is often necessary to also join galvanized constructions such as railings, facade elements, or seawater ballast

Recommended for publication by Commission XVII - Brazing, Soldering and Diffusion Bonding

Philipp Andreazza

philipp.andreazza@igp.fraunhofer.de

Andreas Gericke

andreas.gericke@igp.fraunhofer.de

Knuth-Michael Henkel

knuth.henkel@igp.fraunhofer.de; knuth.henkel@uni-rostock.de

1 Fraunhofer Research Institution for Large Structures in Production Engineering IGP, Albert-Einstein-Straße 30, 18059 Rostock, Germany

2 Chair of Joining Technology, University of Rostock, Albert-Einstein-Straße 30, 18059 Rostock, Germany pipes economically. Due to the high heat input during welding, the zinc evaporates in the arc, which can lead to spattering and pore formation in the weld seam (see Fig. 1 (right)). This can also lead to partial destruction of the zinc layer on the back of the construction. This means that the corrosion-inhibiting function of the coating is no longer given. For this reason, the connecting surfaces must be decoated by grinding or blasting, which is time-consuming and cost-intensive, then welded and finally recoated.

Galvanized seawater ballast pipes, for example, are joined with double sockets to prevent the zinc coating from burning off on the back during welding.

Arc brazing with low-melting copper-based filler materials offers the advantage of lower heat input, which means that the corrosion-inhibiting properties of the coating are largely retained. Due to the formation of a corrosion-inhibiting oxide layer on the brazing materials, recoating of the brazed seam is often not necessary.

Many very interesting studies on the strength properties of arc brazed joints can be found in the literature. For example, in [1], numerous experiments were carried out regarding different arc brazing processes. Particular focus was placed on thin high-strength sheets, which, however, also had an electrolytic 
Fig. 1 Example of galvanized structures in shipbuilding: ballast water pipes (left). Problems by welding galvanized structures: fracture surface of a welded hotdip galvanized cruciform joint $(t=$ $10 \mathrm{~mm}$ ) with numerous pores in weld metal (right)
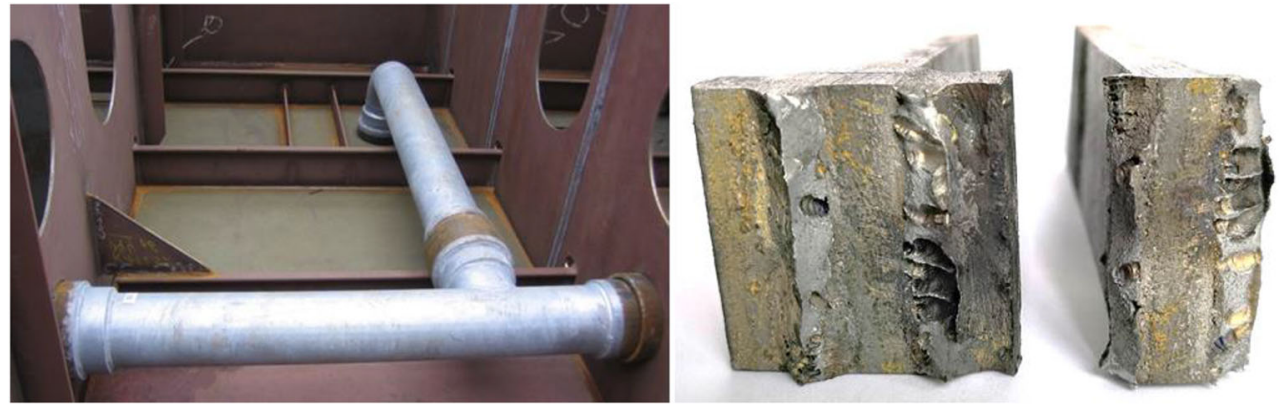

zinc coating. It was shown that this process produces very good joints when filler materials with similar strength to the base sheet are used.

The fatigue behavior was also intensively investigated in the thin sheet sector (see $[2,3]$ ). Sheet thicknesses from 0.8 to $2.4 \mathrm{~mm}$ were designed as various joint geometries and showed advantageous dynamic behavior compared to conventional welded joints.

However, the presented investigations in this paper serve to gain knowledge on the design of both uncoated and hot-dip galvanized arc brazed joints with sheet thicknesses $t>3 \mathrm{~mm}$ in order to adopt them in the state of standardization and thus in practical recommendations for the use of this technology in steel construction and shipbuilding. Thus, the gaps for the sheet thickness range above $3 \mathrm{~mm}$ are to be closed.

In addition to the static and dynamic design of such joints, corrosion-related issues are also of great interest in industrial use. In addition to component safety, corrosion behavior also plays a decisive role, especially with regard to economic aspects. The aim is to clarify whether recoating processes can be avoided if the structural strength of the component is sufficient. These savings can represent a major economic advantage of the technology and thus be superior to classical welding processes. Another important factor in the design of joints is the expected thermal distortion, which must be taken into account or compensated by suitable welding or brazing sequence plans. For this reason, this article presents an innovative method for measuring the distortion tendency of the individual filler metals.

\section{Arc brazing}

In general, brazing is a fusion joining process that is characterized by the use of a dissimilar filler material. Similar or differing materials can be joined by brazing. The atoms at the interface between the base material and the filler metal change places, creating atomic bonding forces [4]. Usually, only the filler material is fused. Capillary behavior, wetting, and diffusion processes are the interface properties of the brazing alloy. The two-sided diffusion occurring as a result of wetting is essentially dependent on the metallic phases that occur, the composition of the atmospheric environment, the process temperature, and the ambient pressure. The formation of intermetallic phases or solid solutions results from a metallurgical reaction [5].

Among other joining processes, arc brazing is mentioned in ISO 4063 [6]. Regulations for arc brazing exist as DVS bulletins 0938-1, 0938-2, and 0938-3 [7-9]. These bulletins contain general information on the basics, processes, system technology, application notes, and information on irregularities. However, the scope of application is explicitly limited to unalloyed or low-alloy steels with plate thicknesses up to $t=3 \mathrm{~mm}$. Arc brazing can be divided into the processes gas metal arc brazing (GMA-B) (see Fig. 2 (left)), tungsten inert gas brazing (TIG-B), and plasma brazing and corresponds as far as possible to GMAW with a flat characteristic in the short and pulse arc, or TIG welding with a steeply dropping characteristic. The difference results from the use of a wire-shaped filler material based on copper. The use of a synthetic core in the hose assembly has proven to be a good solution. The melting ranges of these materials are between approximately 900 and $1100{ }^{\circ} \mathrm{C}$. Fluxes are generally not used. The sheet surface is cleaned and activated by the arc itself, and the inert shielding gas protects the brazing process from the atmosphere. The process is well suited for galvanized structures due to an approximately $60 \%$ lower energy input compared to welding [4].

The liquid metal penetration (LMP), defined in $[9,10]$, is a damage mechanism in brazing technology and describes the penetration of liquid brazing material along the grain boundaries into the base material. This is promoted by a high stress state of the base material and by certain alloying elements.

According to [11], diffusion processes take place between the base material and the brazing metal after the formation of a thin alloy layer. If the joint is under tensile stress, diffusion is uneven, and fused brazing metal, which cannot transfer tensile stress, penetrates into the base material. Cracks can therefore form along the grain boundaries. This happens until the liquid brazing metal can no longer flow to the tip of the crack. Several conditions must be fulfilled for the penetration of liquid brazing material. The filler material must be able to wet the base material, and both must be mutually insoluble. Both materials need to have a similar electronegativity and must not form intermetallic phases. 

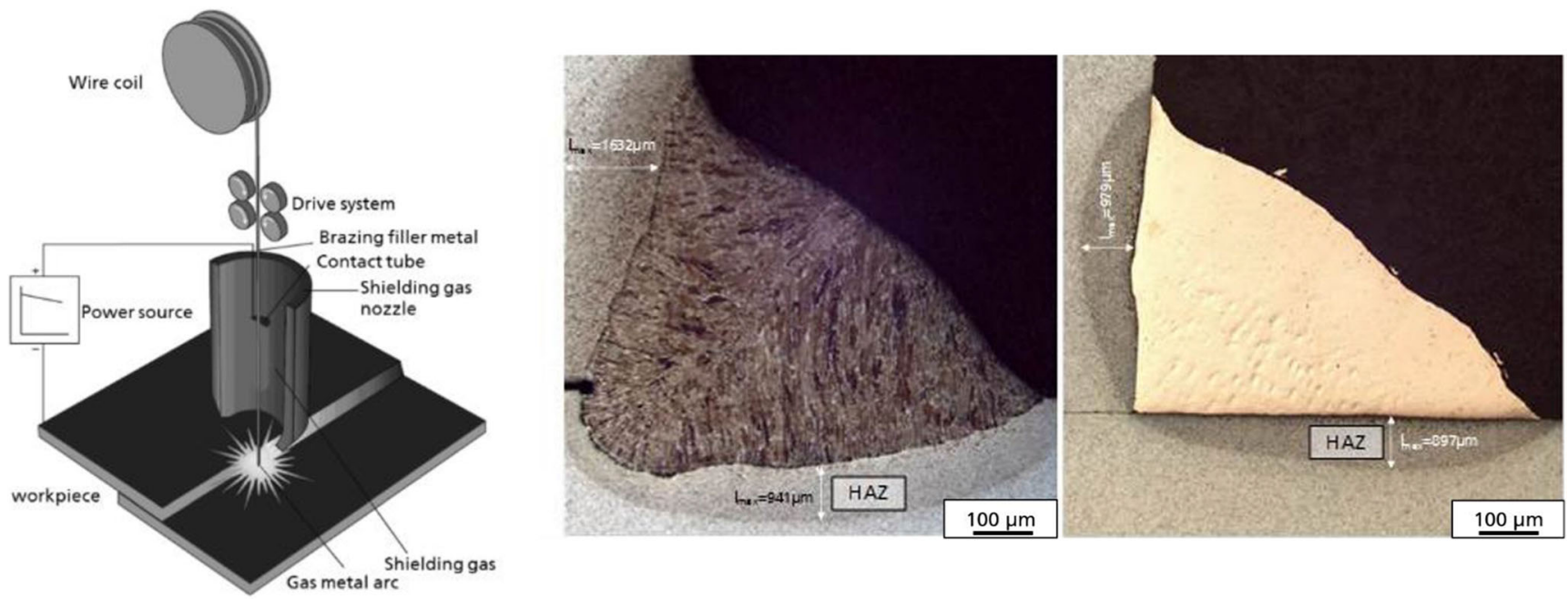

Fig. 2 a Schematic process of gas metal arc brazing with wire shaped filler material [4], b macrosection of a regular fillet weld (left) and an arc brazed fillet seam (right)

\section{Experimental approach}

\subsection{Base and filler materials}

All experiments were carried out on EN 10025-2-S235JR as base material. The chemical composition is listed in Table 1. Three different surface conditions were considered for the build-up brazing: as-rolled (AR), bare ground, and hot-dip galvanized with a zinc layer thickness of approximately 180 $\mu \mathrm{m}$.

Brazing filler metals for arc brazing are copper-based materials with essential solid solution forming alloying elements such as aluminum, nickel, manganese, silicon, and iron. Silicon has a great influence on the flow properties of the brazing alloy, as it lowers the solidus and liquidus temperature together with manganese. Lower silicon contents lead to greater capillary action. Compounds of silicon and iron can lead to the formation of brittle iron silicide in the diffusion zone. Aluminum significantly increases tensile strength and corrosion resistance. According to [12], these materials tend to reduce LMP. The addition of nickel, manganese and iron increases the wear resistance [13].

In the scope of the investigations, 6 different $\mathrm{Cu}$-based brazing alloys were used. The chemical composition and mechanical properties (tensile strength, $R_{m}$; elongation at fracture, $A$ ) are listed in Table 2. The wire diameters varied between 1.0 and $1.2 \mathrm{~mm}$. The alloys CuSi3Mn, CuAl5Ni2Mn, and $\mathrm{CuAl} 7$ are standardized materials, which are well suited for arc brazing of galvanized thin steel sheets. The aluminum bronzes $\mathrm{CuA} 18 \mathrm{Ni} 2 \mathrm{Fe} 2 \mathrm{Mn} 2$ and $\mathrm{CuA} 19 \mathrm{Ni} 5 \mathrm{Fe} 3 \mathrm{Mn} 2$ have high wear resistance and good corrosion resistance. They are mainly used for the production of magnetic valves, ship propellers, and power plant components. They are suitable for both buildup welding and arc brazing. The non-standardized filler material $\mathrm{CuMn} 12 \mathrm{Ni} 2$ was also used.

\subsection{Experimental setup}

A welding machine of the type LORCH S5 SpeedPulse with stored pulse programs was used to carry out the fully mechanized brazing tests. A BUG-GY-VERT II welding tractor from Bug-O-Systems Inc. tracked the torch in a $10^{\circ}$ stabbing position. All brazed seams were carried out in flat position (PA), in which the work piece is right below the torch. This leads to a faster process because the gravity draws the molten filler material downward. Argon 4.6 (ISO 14175-I1) was used as inert shielding gas. In the run-up to the investigations, the brazeability of the individual filler metals was determined by brazing with 11 different parameter variations each. The parameters used for further investigations are listed in Table 3.

Besides the measurement of the wetting angle and the dilution, the diffusion zone was examined metallographically by light and scanning electron microscopy (SEM)/energy dispersive X-ray spectroscopy (EDX) with a JEOL JSM-IT 100. Existing LMP were quantified. In accordance with ISO

Table 1 Chemical composition of EN 10025-2-S235JR

\begin{tabular}{llllllllll}
\hline & $\mathrm{C}$ in wt\% & $\mathrm{Si}$ in wt\% & $\mathrm{Mn}$ in wt\% & $\mathrm{P}$ in wt $\%$ & $\mathrm{~S}$ in wt\% & $\mathrm{N}$ in wt\% & $\mathrm{Cu}$ in wt\% & $\mathrm{Al}$ in wt\% & $\mathrm{Fe}$ in wt\% \\
\hline AR & 0.081 & 0.176 & 0.680 & 0.030 & 0.036 & 0.019 & 0.285 & 0.0042 \\
Galvanized & 0.078 & 0.139 & 0.560 & 0.024 & 0.020 & 0.020 & 0.390 & 0.0039 & 98,29 \\
\hline
\end{tabular}


Table 2 Chemical composition and mechanical properties of used brazing wires, acc. to the manufacturer

\begin{tabular}{|c|c|c|c|c|c|c|c|c|}
\hline Brazing wire & $\mathrm{Cu}$ in $\mathrm{wt} \%$ & $\mathrm{Al}$ in wt $\%$ & $\mathrm{Ni}$ in wt $\%$ & Mn in wt $\%$ & Si in wt $\%$ & $\mathrm{Fe}$ in $\mathrm{wt} \%$ & $\mathrm{R}_{\mathrm{m}}$ in $\mathrm{MPa}$ & $\mathrm{A}$ in $\%$ \\
\hline $\begin{array}{l}\text { BERCOWELD A52 } \\
\text { ISO 24373: Cu } 6061 \\
\text { CuA15Ni2Mn }\end{array}$ & Bal. & $4.50-5.00$ & $1.60-2.00$ & $0.10-0.50$ & - & - & 353 & 45 \\
\hline $\begin{array}{l}\text { BERCOWELD A8 } \\
\text { ISO 24373: Cu } 6100 \\
\text { CuAl7 }\end{array}$ & Bal. & $7.50-8.00$ & $0.10-0.50$ & $0.10-0.30$ & - & - & 430 & 40 \\
\hline $\begin{array}{l}\text { BERCOWELD M122 } \\
\text { CuMn12Ni2 }\end{array}$ & Bal. & - & $2.00-2.50$ & $12.00-13.00$ & - & - & 400 & 40 \\
\hline $\begin{array}{l}\text { BERCOWELD S3 } \\
\text { ISO 24373: Cu } 6560 \\
\text { CuSi3Mn }\end{array}$ & Bal. & - & - & $0.75-0.95$ & $2.80-2.95$ & - & 350 & 40 \\
\hline $\begin{array}{l}\text { BERCOWELD A35 } \\
\text { ISO 24373: Cu } 6328 \\
\text { CuA19Ni5Fe3Mn2 }\end{array}$ & Bal. & $8.50-9.50$ & $4.00-5.00$ & $1.00-2.00$ & - & $3.00-3.50$ & 690 & 16 \\
\hline $\begin{array}{l}\text { BERCOWELD A822 } \\
\text { ISO 24373: Cu } 6327 \\
\text { CuAl8Ni2Fe2Mn2 }\end{array}$ & Bal. & $7.00-9.5$ & $0.50-3.00$ & $0.50-2.50$ & - & $0.50-2.50$ & 530 & 30 \\
\hline
\end{tabular}

15614-1, a hardness test according to DIN EN 6507 was carried out in the brazing metal, in the diffusion zone, in the heataffected zone (HAZ), and in the base material.

To determine the mechanical-technological properties, samples were prepared for quasi-static tensile tests. Two different sample geometries with two different surface conditions (hot-dip galvanized and slightly ground) were investigated. Butt joints for sheet thicknesses of $5 \mathrm{~mm}$ were designed as Ijoints according to ISO 4136 [14], whereby the seam flanks were prepared by saw cutting. The sample length was 300 $\mathrm{mm}$. The brazed seams were executed in two layers (layer + counter layer). The gap widths were varied from 1 to $4 \mathrm{~mm}$, whereby the best root formation was achieved with a gap width of $3 \mathrm{~mm}$. The seam preparation at $t=8 \mathrm{~mm}$ and $10 \mathrm{~mm}$ was carried out as a $\mathrm{V}$-seam. The $\mathrm{V}$-seam preparation was milled out on galvanized sheets, and the milled seam flanks were not post-galvanized.

Cruciform joints with single-layer fillet welds were prepared according to ISO 9018 [15] with a specimen length of $300 \mathrm{~mm}$ and a specimen width of $35 \mathrm{~mm}$. The effective fillet thickness of the fillet seams varied between 5 and $6 \mathrm{~mm}$.

For each series, 6 specimens were tested in a tensile test with a ZwickRoell Z400 universal testing machine. An additional specimen was used for metallographic analysis. The diffusion zone was examined analogous to the build-up brazed seams, the LMP were counted and measured, and the hardness was tested. All samples in each series were taken from a section of brazed sheet metal.

\section{Results and discussion}

\subsection{Bead-on-plate brazed seams}

The use of brazing parameters in the ranges given in Table 3 shows advantageous processing properties with regard to seam appearance and spatter formation on bare and galvanized sheet surfaces. In particular, the two brazing alloys $\mathrm{CuAl} 7$ and CuMn12Ni2 show better processing properties here. The area in the last third of the build-up braze seam was investigated, in which a static process behavior is present. After the metallographic preparation of a cross section, the dilution according to [4], the wetting angle and the number and length of LMP were evaluated for each alloy and surface condition.

It was found that the wetting angles are difficult to compare due to the subjective appearance of the bead (see Table 4). For example, the wetting angle for $\mathrm{CuSi} 3 \mathrm{Mn}, \mathrm{CuAl7}$, and

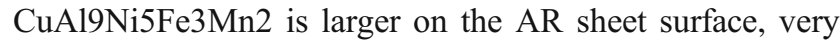
small for $\mathrm{CuAl} 5 \mathrm{Ni} 2 \mathrm{Mn}$ on the AR surface, and almost identical for $\mathrm{CuA} 18 \mathrm{Ni} 2 \mathrm{Fe} 2 \mathrm{Mn} 2$ and $\mathrm{CuMn} 12 \mathrm{Ni} 2$ in all surface conditions.

Table 3 Range of pulsed brazing parameters for EN 10025-2-S235JR

\begin{tabular}{llllllll}
\hline Joint geometry & Position & Current in A & Voltage in V & Travel speed in mm/min & Wire feed rate in m/min & Stickout in mm & Heat input in $\mathrm{kJ} / \mathrm{mm}$ \\
\hline Bead-on-plate & PA & 111 & $20.8-23.2$ & 380 & $4.0-5.7$ & $12-15$ & $0.36-0.41$ \\
Butt joint & PA & $110-118$ & $20.9-23.6$ & 250 & $4.0-6.6$ & 15 & $0.55-0.67$ \\
Fillet joint & PA & $170-190$ & $24.1-26.8$ & 250 & $7.0-9.5$ & 15 & $0.98-1.22$ \\
\hline
\end{tabular}


The degree of dilution is predominantly strongest for the AR condition. The degree of dilution varies between $1.96 \%$ when using $\mathrm{CuA} 19 \mathrm{Ni} 5$ on galvanized surfaces and up to 7.60 $\%$ in the case of $\mathrm{CuAl} 15 \mathrm{Ni} 2 \mathrm{Mn}$ on surfaces in the AR condition.

The number LMP is highest in the AR condition. The most and longest LMP were determined for CuMn12Ni2, $\mathrm{CuAl} 5 \mathrm{Ni2Mn}$, and $\mathrm{CuAl}$ Ni2Fe2Mn2.

The hardness of the braze metal depends largely on the composition of the filler metal. The multicomponent bronzes, especially $\mathrm{CuA} 19 \mathrm{Ni} 5 \mathrm{Fe} 3 \mathrm{Mn} 2$, have the highest hardness from 179 HV10 in the ground condition to 216 HV10 on galvanized surface. The hardness in the diffusion zone is influenced by the surface condition of the sheet as well as by the filler material. It is sometimes higher than in the adjacent HAZ. In the case of galvanized surfaces, the hardness in the diffusion zone is highest because the alloy with the molten zinc leads to solid solution strengthening. This is particularly evident when brazing with $\mathrm{CuAl}$, where a hardness of up to 311 HV10 could be determined. The hardness in the HAZ is not critical with values between 156 and 172 HV10. The unaffected base metal has a hardness of approximately $150 \mathrm{HV} 10$.

The element distributions in the diffusion zone can be evaluated with the help of SEM and EDX analysis. When the $\mathrm{Cu}-$ based filler metal melts due to the heat input of the arc, iron atoms can diffuse into the diffusion zone on the filler metal side, and other alloying elements of the filler metal can diffuse into the diffusion zone on the base material side.

When CuSi3Mn is used, silicon accumulates in the diffusion zone. In the case of aluminum bronzes, aluminum accumulates. The proportion of nickel and manganese (in case of CuMn12Ni2) decreases in the direction of the base material so that a zone is formed in which these elements are evenly distributed together with iron. This causes a partial increase in strength, which is reflected in increased hardness values. In the galvanized sheet surface, the zinc is not distributed in the diffusion zone, but evenly in the brazing metal. Iron atoms diffusing into the brazing material react with atoms of the filler material and can form intermetallic phases such as k-phases (see Fig. 3). The formation mechanism has been investigated in [16].

All the main alloying elements of the brazing alloy as well as zinc, in the case of the galvanized sheet surface, could be detected in the LMP (see Fig. 4).

\subsection{Butt and fillet joints}

\subsubsection{Static strength properties}

The tensile strength of the joints shown in Fig. 5 represent average values from six individual tests with brazed seam failure each.

The tensile strength of the tested cruciform joints for $\mathrm{CuMn} 12 \mathrm{Ni} 2$ and $\mathrm{CuAl} 5 \mathrm{Ni} 2$ with location of fracture in the brazed seam can be found in Fig. 5 in the left diagram. The diagram on the right side shows the tensile strengths of the brazed butt joints which show a better strength behavior compared to cruciform joint. One possible explanation lies in the higher number of brazed seams in the cross-joint specimen, which significantly increases the probability of internal seam irregularities.

In general, the zinc coating has a strength-reducing effect. This is particularly evident when using CuMn12Ni2. Although the tensile strength of $\mathrm{CuAl} 15 \mathrm{Ni} 2 \mathrm{Mn}$ is greater than that of CuMn12Ni2, both brazing materials show similar strength behavior within the joint.

The strength difference between AR and galvanized sheet is lower in the butt joints than in the cross joints because the seam joint of the $\mathrm{V}$-seam was milled. The mixed zinc can therefore only be absorbed into the melt via the edge areas so that the proportion of zinc in the brazed seam is presumably lower than in the cross-joint specimens.

Due to the failure in the braze metal, a calculation of the load-bearing capacity can be carried out.

Using the simplified procedure according to DIN EN 19931-8:2010-12, the load-bearing capacity of the fillet weld $F_{B, R d}$ brazed with $\mathrm{CuMn} 12 \mathrm{Ni} 2$ and $\mathrm{CuAl} 5 \mathrm{Ni} 2 \mathrm{Mn}$ is calculated as follows:

Table 4 Wetting angle and dilution of bead-on-plate brazing of each filler metal on each surface condition

\begin{tabular}{|c|c|c|c|c|c|c|}
\hline \multirow[t]{2}{*}{ Brazing wire } & \multicolumn{3}{|c|}{ Wetting angle in ${ }^{\circ}$} & \multicolumn{3}{|c|}{ Dilution in \% } \\
\hline & Bare & As-rolled & Galvanized & Bare & As-rolled & Galvanized \\
\hline $\mathrm{CuAl} 5 \mathrm{Ni2Mn}$ & 43 & 17 & 33 & 7.1 & 7.1 & 7.6 \\
\hline $\mathrm{CuAl} 7$ & 43 & 52 & 38 & 7.8 & 2.7 & 6.6 \\
\hline CuMn12Ni2 & 32 & 42 & 43 & 2.7 & 5.5 & 1.7 \\
\hline $\mathrm{CuSi3Mn}$ & 43 & 51 & 20 & 2.8 & 6.9 & 2.1 \\
\hline $\mathrm{CuA} 19 \mathrm{Ni} 5 \mathrm{Fe} 3 \mathrm{Mn} 2$ & 50 & 34 & 37 & 5.3 & 6.1 & 2.0 \\
\hline $\mathrm{CuA} 18 \mathrm{Ni} 2 \mathrm{Fe} 2 \mathrm{Mn} 2$ & 47 & 33 & 37 & 3.2 & 7.1 & 5.5 \\
\hline
\end{tabular}



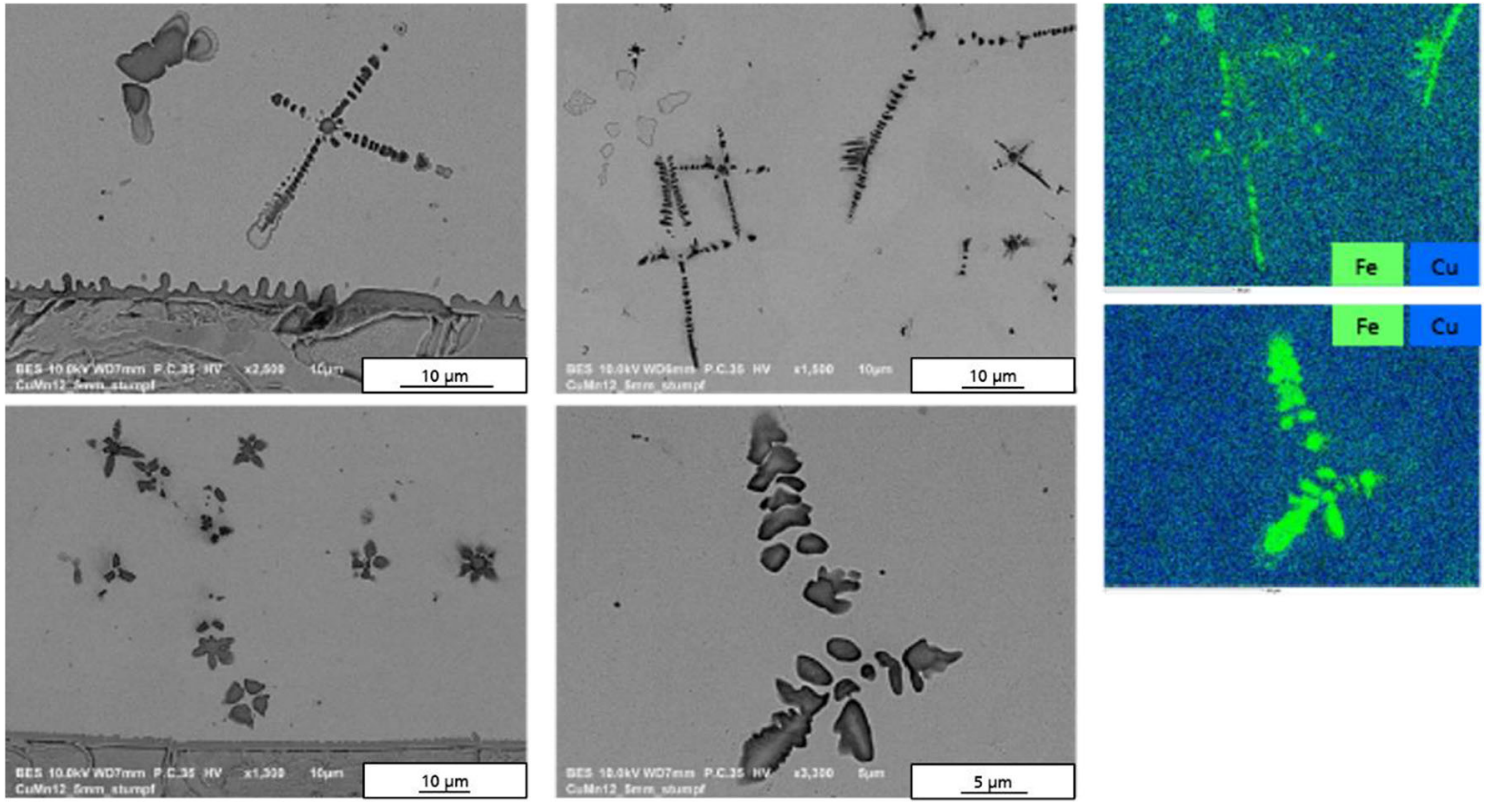

Fig. 3 Backscatter electron SEM-Image and EDX-Analysis of ferrous precipitations in butt joint of CuMn12Ni2 on surface as delivered

$F_{B, R d}=f_{v B, d} \cdot a_{B}$

The design value of the shear strength of the brazed seam $f_{v B, d}$ is given by the following equation:

$f_{v B, d}=\frac{f_{u, B} / \sqrt{3}}{\beta_{B} \cdot \gamma_{M B}}$

where
$a_{B}$
$f_{u, B}$
$\beta_{B}=1,0$
-thickness of fillet weld
$\gamma_{M B}=1,50$
-resistance of the brazing material to fracture
-correlation coefficient
-partial safety factor

To determine the theoretical fracture resistance of the brazing metal, small dimensional tensile specimens (length $=54$ $\mathrm{mm}$, cross section in the measuring range of $2 \mathrm{~mm}^{2}$ ) were taken from brazed fillet welds of the two brazing materials ( $t$ $=8 \mathrm{~mm}, \mathrm{AR}$ and hot-dip galvanized) and tested in a quasistatic tensile test. The actual measured fracture resistance
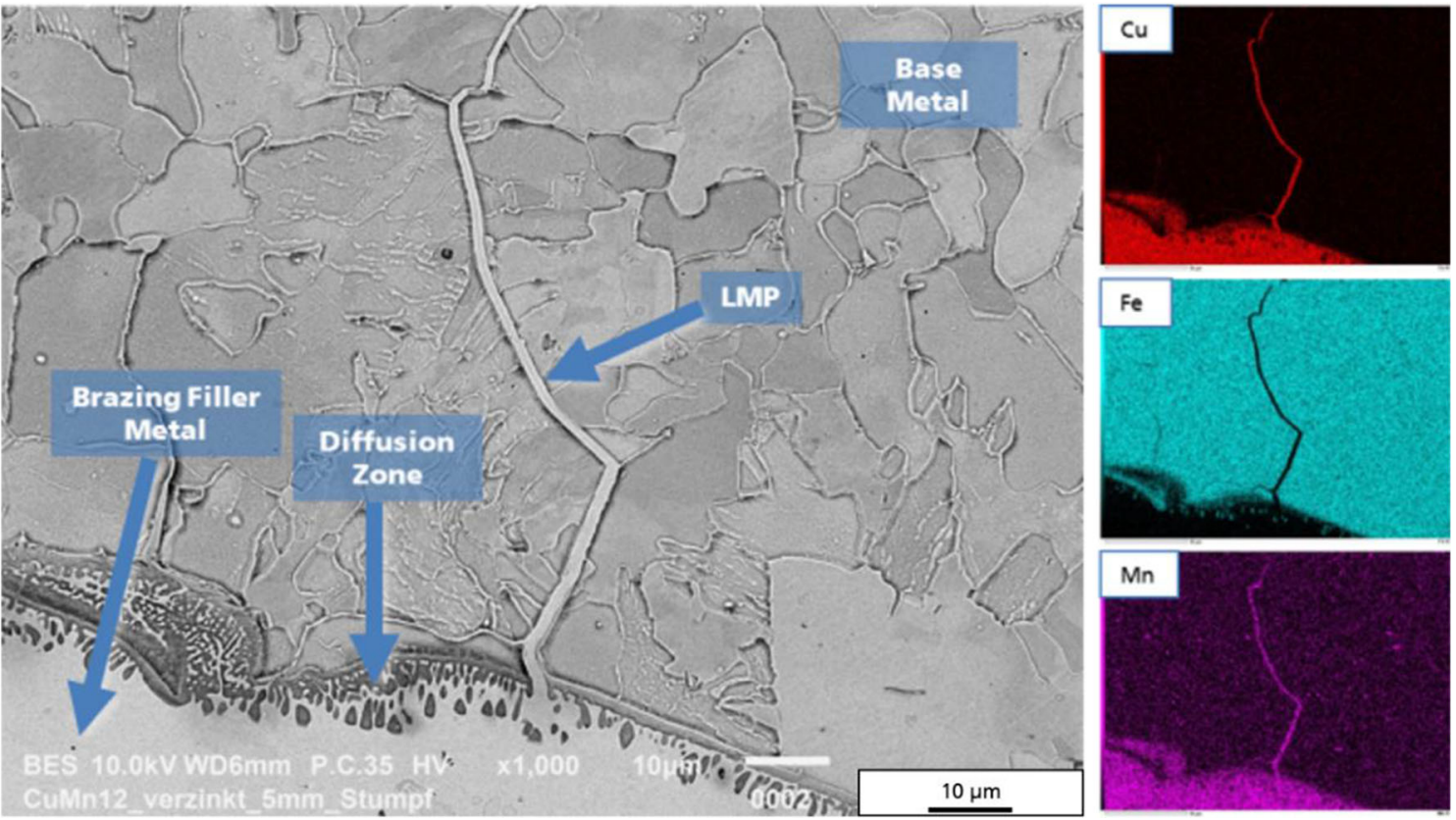

Fig. 4 Backscatter electron SEM-Image and EDX-Analysis of liquid metal penetration in butt joint of CuMn12Ni2 on surface as delivered 
Fig. 5 Tensile strength of cruciform joints (left) and butt joints (right) of CuMn12Ni2 and $\mathrm{CuAl} 5 \mathrm{Ni} 2$ on surface as delivered and hot-dip galvanized

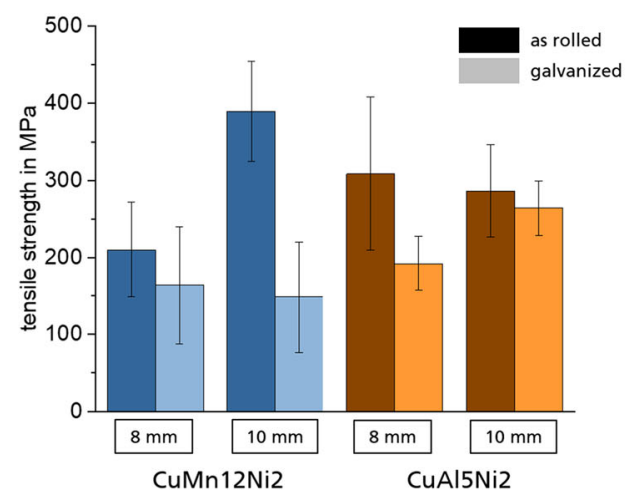

results from the tensile strength of the tested cruciform joint with location of fracture in the brazed seam Table 5.

\subsubsection{Fatigue strength}

The fatigue strength was determined for the brazing alloys CuMn12Ni2 and CuA15Ni2Mn at a plate thickness of $t=$ $8 \mathrm{~mm}$ by means of fatigue tests. For each brazing material, the two sample geometries and surface conditions (for $\mathrm{CuA} 15 \mathrm{Ni2Mn}$ only non-galvanized as cruciform joints) were tested. Conventionally welded, non-galvanized cross-joint test specimens serve as reference. In addition, tensile specimens were taken from build-up welding tests with $\mathrm{CuA} 18 \mathrm{Ni} 2 \mathrm{Fe} 2 \mathrm{Mn} 2$, which represent the basic material behavior of an exemplary brazing material.

The fatigue strength classes (FAT-classes) were generated from 10 individual tests. Using the SincoTec PowerSwing 100 $\mathrm{kN}$ resonance testing machine, a sinusoidal, axially directed stress curve with a load ratio of $R=0.1$ was applied. The evaluation was carried out according to background document EN 1993-1-9 [17]. The fatigue strength class FAT-class with a survival probability of $\mathrm{P}_{\mathrm{u}}=95 \%$ was carried out at $2 \times 10^{6}$ load cycles on the basis of the reference value of the fatigue strength $\Delta \sigma_{\mathrm{c}}$ with both variable and constant gradient of $m=3$ (see Table 6).

According to [18], a misalignment or distortion of the specimen has a great influence on the fatigue strength of arc brazed test specimens due to the introduction of transverse forces during clamping.

In these tests, the crack was made from the root point of the brazed fillet weld.

In general, it can be seen that test specimens with a galvanized sheet surface have a lower fatigue strength (see Table 6). If a variable gradient is assumed, the brazing alloy $\mathrm{CuAl} 5 \mathrm{Ni2} \mathrm{Mn}$ shows a better fatigue strength behavior.

The direction in which the test specimens, taken from build-up welding tests with $\mathrm{CuA} 18 \mathrm{Ni} 2 \mathrm{Fe} 2 \mathrm{Mn} 2$, were taken (perpendicular or longitudinal to the build-up direction) shows no difference in fatigue strength.

Analogous to the tests in [18], the crack was made from the root point of the MIG-brazed fillet seam.

\subsection{Metallography}

Analogous to the bead-on-plate brazing, the butt joints and cruciform joints were prepared metallographically to examine

Table 5 Shear strength $f_{v B, d}$, breaking strength $f_{u, B}$, and load-bearing capacity $F_{B, R d}$ of fillet welds as well as strengths of butt joints for CuAl5Ni2Mn and CuMn12Ni2

\begin{tabular}{|c|c|c|c|c|c|c|c|c|c|c|}
\hline & & & \multicolumn{6}{|l|}{ Fillet joint } & \multirow{2}{*}{\multicolumn{2}{|c|}{ Butt joint }} \\
\hline & & & $\mathrm{f}_{\mathrm{vB}, \mathrm{d}}$ in $\mathrm{MPa}$ & & $\mathrm{f}_{\mathrm{u}, \mathrm{B}}$ in $\mathrm{MPa}$ & & $\mathrm{F}_{\mathrm{B}, \mathrm{Rd}}$ in $\mathrm{N} / \mathrm{mm}$ & & & \\
\hline \multirow{5}{*}{$\begin{array}{l}\text { Brazing wire } \\
\mathrm{CuAl} 5 \mathrm{Ni} 2 \mathrm{Mn}\end{array}$} & $t$ in $\mathrm{mm}$ & Surface & Theoretically & Measured & Theoretically & Measured & Theoretically & Measured & $\mathrm{R}_{\mathrm{p} 0,2}$ in $\mathrm{MPa}$ & $\mathrm{R}_{\mathrm{m}}$ in $\mathrm{MPa}$ \\
\hline & 8 & $\mathrm{AR}$ & 134 & 119 & 348 & 309 & 1072 & 1292 & 279 & 468 \\
\hline & & Galvanized & 147 & 74 & 382 & 192 & 1176 & 655 & 317 & 441 \\
\hline & 10 & $\mathrm{AR}$ & 134 & 110 & 348 & 287 & 1072 & 1133 & 274 & 363 \\
\hline & & Galvanized & 147 & 102 & 382 & 264 & 882 & 828 & 245 & 358 \\
\hline \multirow[t]{4}{*}{ CuMn12Ni2 } & 8 & $\mathrm{AR}$ & 125 & 81 & 325 & 211 & 1000 & 812 & 292 & 465 \\
\hline & & Galvanized & 125 & 63 & 325 & 164 & 1002 & 673 & 217 & 463 \\
\hline & 10 & $\mathrm{AR}$ & 125 & 150 & 325 & 390 & 1000 & 1450 & 260 & 400 \\
\hline & & Galvanized & 125 & 57 & 325 & 148 & 1002 & 610 & 266 & 379 \\
\hline
\end{tabular}


Table 6 FAT-classes of the fatigue tests

\begin{tabular}{|c|c|c|c|c|c|c|}
\hline \multirow[t]{2}{*}{ Brazing wire } & & \multicolumn{2}{|l|}{ Butt joint } & \multicolumn{2}{|l|}{ Fillet joint } & \multirow[t]{2}{*}{ Brazing metal } \\
\hline & & Non-galvanized & Galvanized & Non-galvanized & Galvanized & \\
\hline \multirow[t]{2}{*}{$\mathrm{CuAl} 5 \mathrm{Ni2Mn}$} & $\mathrm{m}=$ var. & 90 & 71 & 56 & - & - \\
\hline & $\mathrm{m}=3$ & 56 & 80 & 36 & - & - \\
\hline \multirow[t]{2}{*}{$\mathrm{CuMn} 12 \mathrm{Ni} 2$} & $\mathrm{~m}=$ var. & 50 & 50 & 50 & 45 & - \\
\hline & $\mathrm{m}=3$ & 45 & $<36$ & 36 & 50 & - \\
\hline \multirow[t]{2}{*}{ G3Si1 } & $\mathrm{m}=$ var. & - & - & 90 & - & - \\
\hline & $\mathrm{m}=3$ & - & - & 80 & - & - \\
\hline $\mathrm{CuA} 18 \mathrm{Ni} 2 \mathrm{Fe} 2 \mathrm{Mn} 2$ & $m=3$ & - & - & - & - & $>160$ \\
\hline
\end{tabular}

the diffusion zone by means of SEM, to count and measure the LMP optically, and to analyze the hardness distribution. Table 7 shows as an example the number and length of the LMP of the butt joints with galvanized and AR sheet metal surfaces.

Obviously, in the case of the galvanized surface, most LMP occur when using $\mathrm{CuA15Ni2Mn}$ and CuMn12Ni2. When brazing with $\mathrm{CuA} 18 \mathrm{Ni} 2 \mathrm{Fe} 2 \mathrm{Mn} 2$, most LMP occur on AR condition. Very few LMP occur with $\mathrm{CuSi} 3 \mathrm{Mn}$ regardless of the surface finish. A correlation with the quasi-static tensile tests of the butt joints with 5-mm plate thickness shows that the occurrence of LMP in the plate thickness range considered does not have a strength-reducing effect. In the case of the two bronzes $\mathrm{CuAl} 5 \mathrm{Ni} 2 \mathrm{Mn}$ and $\mathrm{CuMn} 12 \mathrm{Ni} 2$, the failure occurred mainly in the base material. Individual samples failed in the brazing material but not in the diffusion zone so that it can be assumed that a secure bond can be ensured despite LMP.

\subsection{Corrosion behavior}

The already mentioned reduced heat input by arc brazing is mainly intended to maintain the corrosion protection of galvanized steel structures. In order to prove this, test specimens were stored for 4 weeks (cycles) in salt spray tests according to DIN EN ISO 9227 [19]. For this purpose, fillet welds were carried out on hot-dip galvanized S235JR with sheet thicknesses of $5 \mathrm{~mm}, 8 \mathrm{~mm}$, and $10 \mathrm{~mm}$ with the same heat input and thus the same thickness of the fillet seam. CuSi3Mn was used as the brazing filler material and compared with a welded reference (G3Si1), also with the same thickness of the fillet weld. Five samples were produced per series so that a total of 30 samples could be documented macroscopically each week. The development of rust on the back of the samples is particularly critical. This represents constructions that can only be welded on one side, such as pipes. A corrosion protection cannot be applied there from the inside afterwards.

Already after the first cycle, clear signs of red rust on the weld seam and the adjacent area could be detected in the welded reference, irrespective of the plate thickness. In the case of the samples with a sheet thickness of $5 \mathrm{~mm}$, this could also be documented on the back of the sample (Fig. 6 (middle)). From the fourth cycle onwards, the thicker sheet thicknesses show signs of rust on the rear side (Fig. 6 (right)).

Arc brazed test specimens show an inert corrosion behavior of the brazed seam and the seam adjacent area. Regardless of the sheet thickness, no red rust could be detected on the back of the test specimen after four cycles.

\subsection{Multi-layer brazing}

Just as with welding, certain joint geometries require the execution in several layers. The locally high heat applied can lead to distortion due to thermal expansion and possibly to internal stresses in connection with structural transformation.

Table 7 Number and length of LMP for butt joints $(t=5 \mathrm{~mm})$

\begin{tabular}{|c|c|c|c|c|}
\hline \multirow[t]{2}{*}{ Brazing wire } & \multicolumn{2}{|c|}{ Uncoated surface } & \multicolumn{2}{|c|}{ Zinc-coated surface } \\
\hline & Number & Total length in $\mu \mathrm{m}$ & Number & Total length in $\mu \mathrm{m}$ \\
\hline $\mathrm{CuA15Ni2Mn}$ & 20 & 3576 & 19 & 1980 \\
\hline $\mathrm{CuAl} 7$ & 18 & 3579 & 5 & 708 \\
\hline CuMn12Ni2 & 18 & 3152 & 19 & 1477 \\
\hline CuSi3Mn & 18 & 2859 & 4 & 395 \\
\hline $\mathrm{CuA} 19 \mathrm{Ni} 5 \mathrm{Fe} 3 \mathrm{Mn} 2$ & 17 & 3183 & 5 & 577 \\
\hline $\mathrm{CuA} 18 \mathrm{Ni} 2 \mathrm{Fe} 2 \mathrm{Mn} 2$ & 36 & 6062 & 5 & 516 \\
\hline
\end{tabular}


However, this is critical in the case of $\mathrm{Cu}$-based materials, as they have 1.4 times the thermal expansion and 2 times the shrinkage of steel. In order to determine the suitability for multi-layer brazing of the brazing materials already presented, fillet welds consisting of a root layer and two cover layers were created and metallographically examined Fig 7 and 8 .

It could be shown that when using $\mathrm{CuA} 15 \mathrm{Ni} 2 \mathrm{Mn}$, $\mathrm{CuAl} 8 \mathrm{Ni2} 2 \mathrm{Fe} 2 \mathrm{Mn} 2$, and $\mathrm{CuAl} 7$, the reheated microstructure in the root layer was predominantly homogeneous and finegrained. When brazing CuMn12Ni2 and CuA19Ni5Fe3Mn2, there is no influence of reheating.

The brazing alloy CuSi3Mn, which is widely used in the automotive industry, is a special case. Here, cracks in the top layer were detected, which probably result from an unfavorable ratio of a high thermal expansion coefficient and low tensile strength. This area of the brazing material is characterized by the last solidified primary structure with portions of residual melt, which is why it exhibits an equiaxial dendritic structure. This material is not suitable for a multi-layer seam design.

\subsection{Distortion tendency}

Since the influences of thermal expansion, residual stresses, and microstructural transformations on the distortion during arc brazing with copper-based materials have not yet been investigated in sufficient detail, an innovative test stand (Fig. 9) was used to measure the reaction force during brazing. This new method enables the opportunity to compare the angular distortion tendency of the individual brazing alloys while taking the energy input into account, in situ.

The brazing alloys CuSi3Mn, CuMn12Ni2, CuA15Ni2Mn,

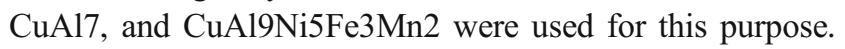

The comparison to a welded reference was made by welding with the wire material G4Si1. This was carried out using fillet seams in both single and multiple layers. The thickness of the fillet weld was kept constant within the series.

Significant differences between the individual filler materials could be demonstrated. In multi-layer brazing or welding, the reaction forces increase successively (see Fig. 10).

Thus, the lowest reaction force maxima (in relation to the heat input) occurred when brazing with CuAl5Ni2Mn $(3.9 \mathrm{~N} /$ $\mathrm{kJ}$ single-layer or $5.9 \mathrm{~N} / \mathrm{kJ}$ multi-layer) and CuAl7 $(5 \mathrm{~N} / \mathrm{kJ}$ or $15.1 \mathrm{~N} / \mathrm{kJ}$ ). Low forces in the range of $3 \mathrm{~N} / \mathrm{kJ}$ and $7 \mathrm{~N} / \mathrm{kJ}$ were also measured when welding with G4Sil. The highest reaction forces were achieved when brazing with CuMn12Ni2 $(10.6 \mathrm{~N} / \mathrm{kJ}$ and $49.6 \mathrm{~N} / \mathrm{kJ}), \mathrm{CuSi} 3 \mathrm{Mn}(9 \mathrm{~N} / \mathrm{kJ}$ and 30.4 $\mathrm{N} / \mathrm{kJ})$, and CuA19Ni5Fe3Mn2 (10.4 N/kJ and $28.9 \mathrm{~N} / \mathrm{kJ})$.

The maximum of the reaction force is reached after about 10 to $15 \mathrm{~min}$. The crystal lattice transformation as a function of thermal conductivity and the cooling rate have an influence on the tendency to distort. It has been shown that filler materials with a homogeneous microstructure over the entire seam area tend to produce higher distortion forces. The combination of thermal expansion coefficient and strength also has a dominant influence here.

\section{Conclusion and outlook}

Within the research project, six different copper-based materials were examined for their practical suitability for use in steel construction. The general processing properties, such as seam formation, wetting, dilution, and spattering behavior, were analyzed in the context of build-up brazing on plates with three different surface conditions, whereby the two
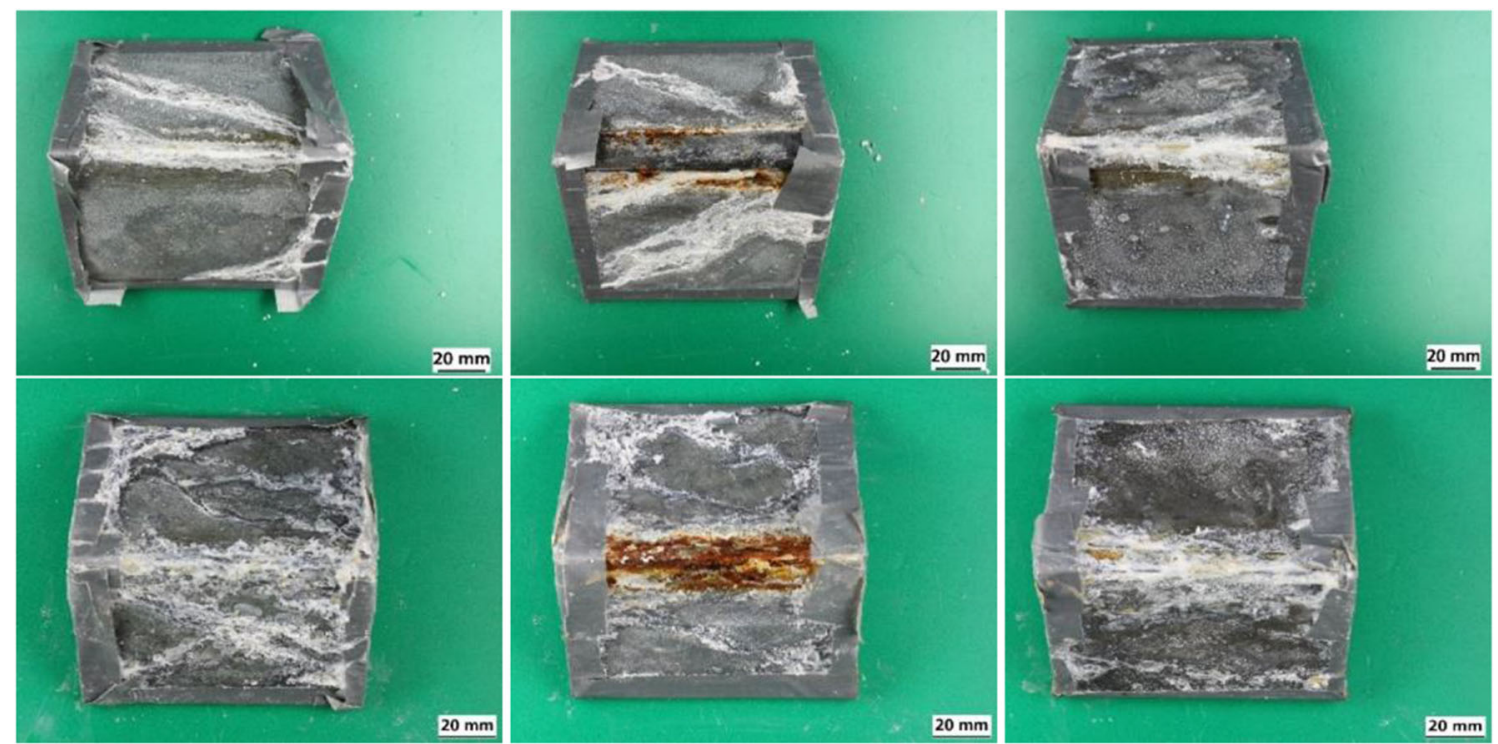

Fig. 6 Back of test specimen after corrosion test: upper row after 1 week of aging, lower row after four weeks of aging; CuSi3Mn $t=5 \mathrm{~mm}($ left), G3Si1 $t$ $=5 \mathrm{~mm}$ (middle), and G3Sil $t=10 \mathrm{~mm}$ (right) 


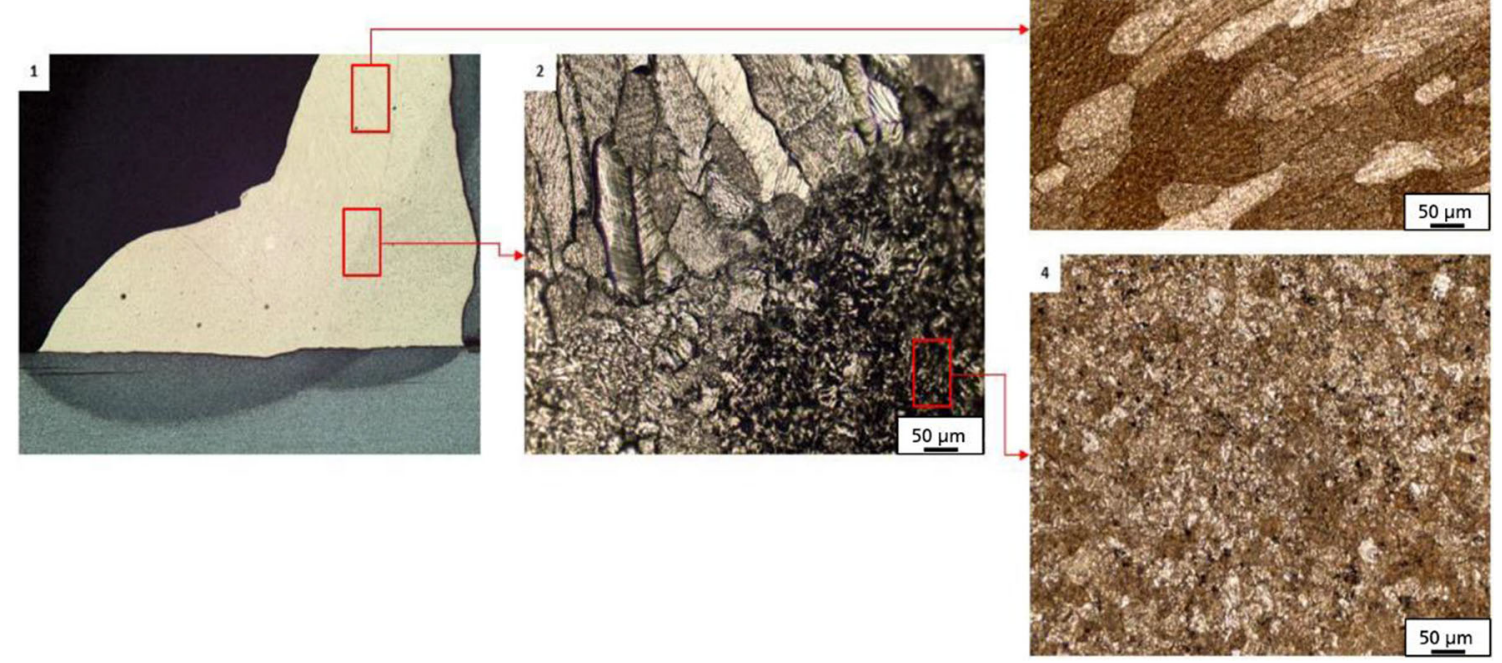

Fig. 7 Micro section of multi-layer brazed fillet seam with $\mathrm{CuAl}$ Ni2Mn with predominantly homogeneous microstructure in the root layer

brazing alloys $\mathrm{CuMn} 12 \mathrm{Ni} 2$ and $\mathrm{CuAl} 7$ proved to be particularly advantageous for use on galvanized plate surfaces.

To describe the static strength behavior, quasi-static tensile tests were carried out on as-rolled and galvanized sheet surfaces $(t=5 \mathrm{~mm})$ for two different geometries. In the case of $\mathrm{CuA19Ni5}$ and CuMn12Ni2, the fracture position could be detected in the uncoated case mainly in the unaffected base material and in the case of $\mathrm{CuAl} 5 \mathrm{Ni} 2 \mathrm{Mn}$, independently of the sheet surface condition, also in the base material. This shows that these filler metals are suitable for the application of sheet thicknesses above $3 \mathrm{~mm}$.
For tensile tests of sheet thicknesses of $8 \mathrm{~mm}$ and 10 $\mathrm{mm}$, the two brazing alloys CuMn12Ni2 and $\mathrm{CuAl}$ Ni2Mn were used. Special care was taken to cause a braze seam failure so that the load-bearing capacity of the fillet seams of cruciform joint specimens could be calculated using a simplified method according to EC3, which is important to be incorporated into the design of the brazed structures. The expected strength-reducing effect of a galvanized sheet surface of cruciform joint specimens could be shown. Nevertheless, the experiments made it clear that the strength behavior deteriorates noticeably as the number of brazed seams increases.
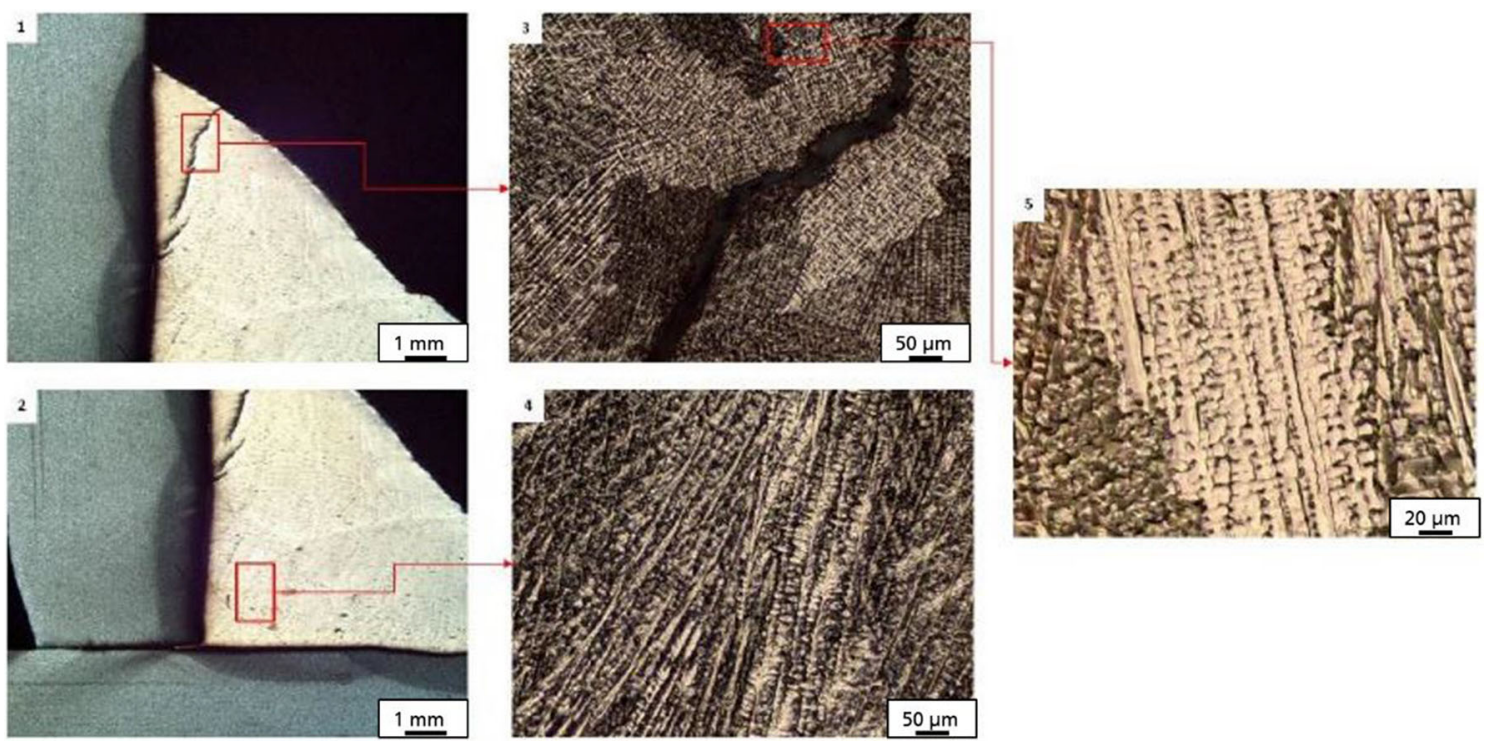

Fig. 8 Micro section of multi-layer brazed fillet seam with CuSi3Mn with cracks in the top layer 
Fig. 9 Reaction force measurement: schematic diagram of the experimental stand (left), experimental stand before joining with inserted plates, and attached force measuring ring (right)
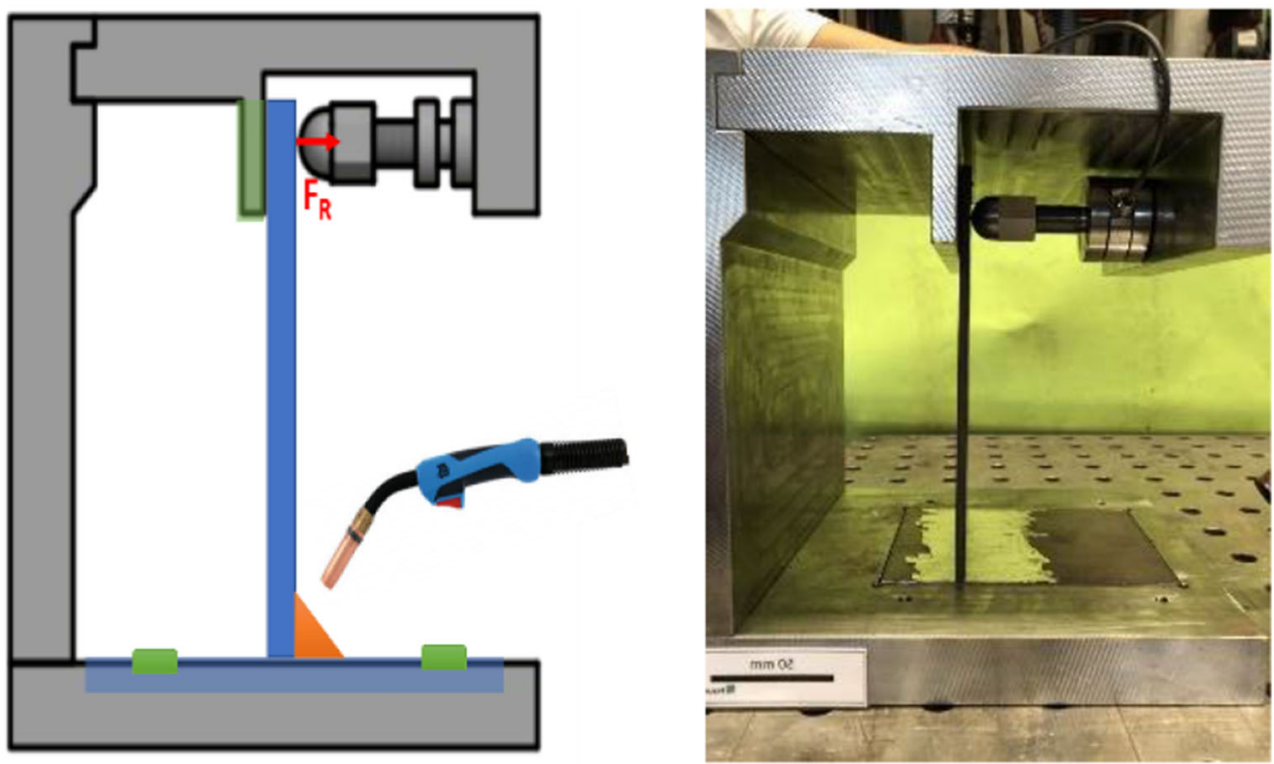

In addition, fatigue tests were carried out, whereby it could be shown that test specimens with a galvanized sheet surface have a lower fatigue strength. This fatigue strength behavior can be observed analogously to the static tests. If a variable gradient is assumed, the brazing alloy $\mathrm{CuAl} 5 \mathrm{Ni} 2 \mathrm{Mn}$ shows a better fatigue strength behavior. The initial crack occurred in the root point of the brazed seam which was also shown in experiments from the literature.

Salt spray tests have shown the advantageous, reduced heat input in arc brazing of galvanized structures compared to conventional welding. During welding, red rust appeared on the back of the test specimen after one $(t=5$ $\mathrm{mm})$ or 4 cycles $(t=10 \mathrm{~mm})$, irrespective of the sheet thickness examined.

In contrast, the corrosion-inhibiting effect of hot-dip galvanizing on the back of the test specimen remains intact during arc brazing. The experiments show the major economic advantage of the technology. From a sheet thickness of $5 \mathrm{~mm}$, the back zinc layer is not destroyed, but merely recrystallizes.
For this reason, the corrosion-inhibiting function of the zinc coating is still given. Post-coating processes can therefore be saved.

In order to increase the bonding surface of the filler metal, it is necessary to work in several layers, as in welding. So it becomes clear that the brazing alloys, whose physical properties are very different from the iron-based filler materials, must be suitable for multi-layer brazing. The experiments show that when multi-layer brazing CuAl5Ni2Mn, CuA18Ni2Fe2Mn2, and $\mathrm{CuAl}$, the reheated microstructure in the root layer is primarily homogeneous and fine-grained. When brazing $\mathrm{CuMn} 12 \mathrm{Ni} 2$ and $\mathrm{CuA} 19 \mathrm{Ni} 5 \mathrm{Fe} 3 \mathrm{Mn} 2$, there is no influence of the reheating; therefore, these brazing alloys are to be classified as suitable for multi-layer brazing. Multi-layer brazing with $\mathrm{CuSi} 3 \mathrm{Mn}$ on the other hand showed cracks in the top layer, which probably result from an unfavorable ratio of a high thermal expansion coefficient and low tensile strength. However, this widely used alloy is not suitable for multi-layer design of brazed joints.
Fig. 10 Reaction force measurement: comparison of the reaction forces of the individual filler materials in multi-layer design

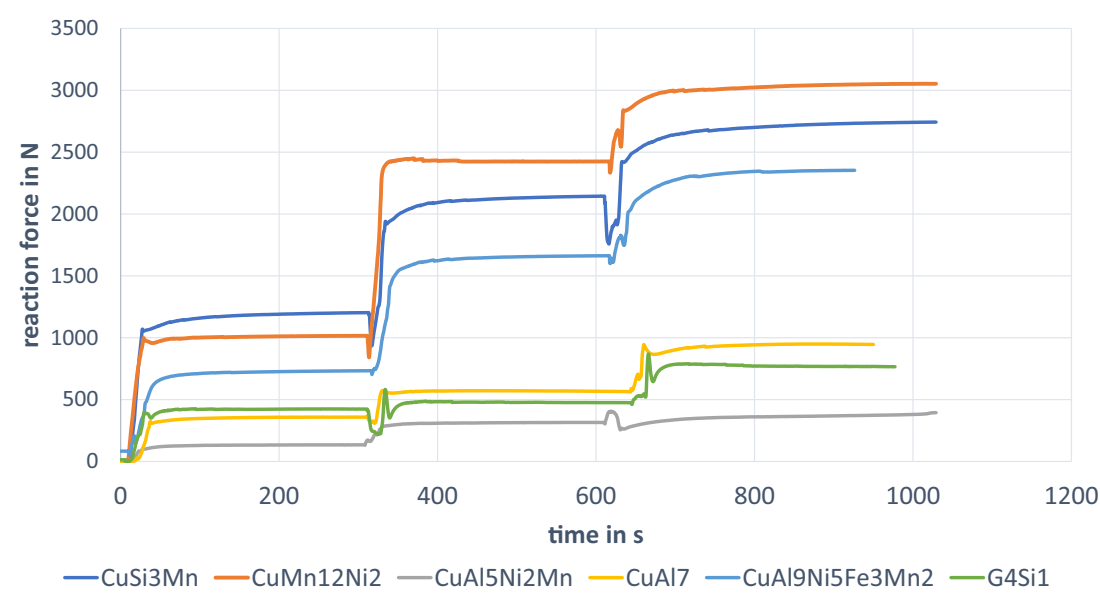


A new method for quantifying angular distortion has been presented in this paper. It was shown that the measurement of the occurring reaction force is suitable to express the tendency to distortion of the filler materials in situ. Thus, by including the energy input, a comparison of the distortion tendency of the filler materials can be made. With $\mathrm{CuAl} 5 \mathrm{Ni} 2 \mathrm{Mn}$ and $\mathrm{CuAl} 7$ the lowest and with CuMn12Ni2 and CuSi3Mn the highest, reaction forces could be measured. An interesting result is that welding with G4Sil causes similarly low reaction forces as $\mathrm{CuAl} 15 \mathrm{Ni} 2 \mathrm{Mn}$. This data can be used in the industry to create welding sequence plans to avoid unnecessary thermal distortion.

However, in the future, a lot of work has to be done in order to expand this measurement method to other forms of distortion so that extensions to the test rig are being planned.

In order to ensure broad applicability, future steps will attempt to anchor the design of arc brazed joints for steel construction in corresponding standards and guidelines. Current developments in the industry, such as the general technical approval/type approval Z-30.6-76 for the use of arc brazing on galvanized steel structures, show the industrial interest and future potential.

Funding This work was made within the IGF research project 19894 BR "Einfluss von fertigungstechnischen und geometrischen Parametern auf die Betriebstauglichkeit lichtbogengelöteter verzinkter Stahlkonstruktionen $\mathrm{t}>3 \mathrm{~mm}$ " of the Research Association on Welding and Allied Processes of the DVS and has been funded by the AiF within the program for sponsorship by Industrial Joint Research (IGF) of the German Federal Ministry of Economic Affairs and Energy on the basis of a decision of the German Bundestag. Open access funding provided by Open Access funding enabled and organized by Projekt DEAL.

Open Access This article is licensed under a Creative Commons Attribution 4.0 International License, which permits use, sharing, adaptation, distribution and reproduction in any medium or format, as long as you give appropriate credit to the original author(s) and the source, provide a link to the Creative Commons licence, and indicate if changes were made. The images or other third party material in this article are included in the article's Creative Commons licence, unless indicated otherwise in a credit line to the material. If material is not included in the article's Creative Commons licence and your intended use is not permitted by statutory regulation or exceeds the permitted use, you will need to obtain permission directly from the copyright holder. To view a copy of this licence, visit http://creativecommons.org/licenses/by/4.0/.

\section{References}

1. Chovet C, Guiheux S (2005) Possibilities offered by MIG and TIG brazing of galvanized ultra high strength steels for automotive applications. International Conference Super High Strength Steels, organised by AIM, Roma 2-4-novembre 2005

2. Sehram A, Masendorf R, Medhurst T, Wiche H (2008) Manufacturing and Fatigue Strength of Brazed, Locally Hardened Structures. Mater Technol Steel Res Int 79(2008):3. https://doi.org/ 10.2374/SRI07SP127-79-2008-219-224

3. Basak S, Pal KT, Shome M (2015) High-cacle fatigue behavior og MIG brazed galvanized DP600 steel sheet joint - effect of process parameters. Springer-Verlag London 2015. Int J Adv Manuf Technol (2016) 82:1197-1211. https://doi.org/10.1007/s00170015-7451-1

4. Dilthey U (2006) Schweißtechnische Fertigungsverfahren 1. Springer-Verlag Berlin-Heidelberg. https://doi.org/10.1007/3-54033154-9

5. Beckert M, Neumann A (1973) Grundlagen der Schweißtechnik. Bd.: Löten, VEB Verlag Technik. Berlin https://doi.org/10.1002/ maco.19730240131

6. ISO 4063:2011-03 (2011): Welding and allied processes - nomenclature of processes and reference numbers

7. DVS 0938-1 (2012) Lichtbogenlöten - Grundlagen, Verfahren. Anforderungen an die Anlagentechnik. DVS Media GmbH, Düsseldorf

8. DVS 0938-2 (2005) Lichtbogenlöten - Anwendungshinweise. DVS Media GmbH, Düsseldorf

9. DVS 0938-3 (2012) Lichtbogenlöten - Unregelmäßigkeiten und Hinweise zu deren Vermeidung. DVS Media GmbH, Düsseldorf

10. Pasewald K (2004) Erscheinungsformen von Rissen und Brüchen metallischer Werkstoffe. Verlag Stahleisen GmbH, Düsseldorf. https://doi.org/10.1002/maco.19970481011

11. Kauczor E (1979) Metallographie in der Schadensuntersuchung. Springer-Verlag Berlin-Heidelberg. https://doi.org/10.1007/978-3642-81335-1

12. Dies K (1967) Kupfer und Kupferlegierungen in der Technik. Springer-Verlag Berlin-Heidelberg. https://doi.org/10.1007/978-3642-48931-0

13. Ebbinghaus $M$ (2014) Untersuchung der Verarbeitungseigenschaften von Kupferbasiszusatzwerkstoffen im MIG- und Laserlötprozess an Stahlblechen mit unterschiedlichem Festigkeitsverhalten. Dissertation. TU Chemnitz

14. DIN EN ISO 4136 (2012) Zerstörende Prüfung von Schweißverbindungen an metallischen Werkstoffen Querzugversuch

15. DIN EN ISO 9018 (2015) Zerstörende Prüfung von Schweißverbindungen an metallischen Werkstoffen - Zugversuch am Doppel-T-Stoß und Überlappsto $\beta$

16. Yu Z, Li R, Qi K (2006) Growth behavior of interfacial compounds in galvanized steel joints with $\mathrm{CuSi} 3$ filler under arc brazing. Trans Nonferrous Metals Soc China 16(6):1391-1396. https://doi.org/10. 1016/S1003-6326(07)60026-0

17. DIN EN 1993-1-8:(2010)-12 Eurocode 3: Bemessung und Konstruktion von Stahlbauten - Teil 1-8: Bemessung von Anschlüssen.

18. Lepistö JS (2004) MIG Brazing as a means of fatigue life improvement. Weld World 48(9/10):2004

19. DIN EN ISO 9227:(2017)-07 Korrosionsprüfungen in künstlichen Atmosphären-Salzsprühnebelprüfungen

Publisher's note Springer Nature remains neutral with regard to jurisdictional claims in published maps and institutional affiliations. 